\title{
Utilization of Infrared Thermography in Cattle Production and Its Application Potency in Indonesia
}

\section{(Pemanfaatan Termografi Inframerah pada Usaha Peternakan Sapi dan Potensi Penggunaannya di Indonesia)}

\author{
Hadriana Bansi \\ Maluku Assessment Institute for Agricultural Technology \\ Jl. Chr. Soplanit Rumah Tiga, Ambon, Indonesia \\ dianabansi@yahoo.com
}

(Diterima 31 Mei 2018 - Direvisi 6 Agustus 2018 - Disetujui 4 September 2018)

\begin{abstract}
Infrared thermography (IRT) is a non-invasive remote sensing method to detect temperature. Many studies have shown that temperature in several regions of the body could be representative of core body temperature. Body temperature of cattle can be used to evaluate health status, stress, thermal balance, and feed efficiency. The aim of this article is to review utilization of IRT in cattle production system and its potency to be applied in Indonesia. The ability of IRT to detect even the small change of body surface temperature has made this device is very useful in cattle production industry. Infrared thermography has been used as a tool to detect an early detection of inflammation as sign of some diseases such as mastitis, foot and mouth disease. Infrared thermography can also evaluate feed efficiency through detection of heat production produced by metabolism process. Some important constraints of cattle production in Indonesia such as diseases and low feed efficiency may have strong correlation with body temperature change. Therefore, IRT is very potential to be applied in cattle farms in Indonesia.
\end{abstract}

Key words: Infrared thermography, body temperature, cattle

\begin{abstract}
ABSTRAK
Termografi inframerah (IRT) adalah metode non-invasif penginderaan jarak jauh untuk mendeteksi suhu. Beberapa hasil penelitian menyatakan bahwa suhu pada beberapa bagian tubuh merupakan representasi dari suhu tubuh. Suhu tubuh sapi dapat digunakan nuntuk mengevaluasi kondisi kesehatan, tingkat stres, keseimbangan suhu tubuh dan efisiensi pakan. Makalah ini bertujuan untuk menelaah pemanfaatan dan aplikasi IRT pada usaha peternakan sapi dan potensi penerapannya di Indonesia. Kemampuan IRT untuk mendeteksi perubahan suhu tubuh permukaan yang sangat kecil menjadikan alat ini sangat efisien digunakan pada usaha peternakan sapi. Termografi inframerah sudah digunakan sebagai alat deteksi dini beberapa penyakit inflamasi seperti halnya mastitis, penyakit mulut dan kuku. Termografi inframerah juga dapat digunakan untuk mengevalusi efisiensi pakan melalui deteksi produksi panas tubuh yang dihasilkan oleh proses metabolisme. Beberapa penghambat utama pada usaha peternakan sapi di Indonesia adalah penyakit dan rendahnya efisiensi pakan. Kedua penghambat tersebut erat kaitannya dengan perubahan suhu tubuh. Oleh karena itu, IRT sangat berpotensi untuk diaplikasikan pada peternakan sapi di Indonesia.
\end{abstract}

Kata kunci: Termografi inframerah, suhu tubuh, sapi

\section{INTRODUCTION}

Infrared thermography (IRT) is a non-invasive remote sensing method to detect temperature. Infrared thermography was able to detect less than $1{ }^{\circ} \mathrm{C}$ temperature change in the cattle suspect with bovine viral diarrhoea virus (BVDV) (Schaefer et al. 2004). In comparison with traditional method thermometers, such as the rectal thermometer, tympani thermometer, and thermal microchip, IRT was easier and less invasive (Johnson et al. 2011; Timsit et al. 2011). Usamentiaga et al. (2014) outlined the advantages of
IRT measurement of temperature as follows: Firstly, as a non-contact technology which means no need to put IRT directly to targeted object, IRT will be useful and safe to measure dangerous objects or something extremely hot, and also convenient for remote measurement especially for a targeted live object such as human and animal. Secondly, IRT results a two dimensional thermogram (thermal-images) which allows easy comparison between areas of the target image. The temperature of two dimensional images can be measured by infrared technology which helps to compare areas between target objects. Thirdly, IRT is a 
real time tool. In comparison with other radiation technologies such as X-ray imaging, IRT has no harmful effects.

Many studies have shown that temperature in several regions of the body could be representative of core body temperature. Therefore, IRT has been used to measure core body temperature by measuring the temperature in appropriate regions of the body surface. For instance, eye temperature in the lacrimal area has a high correlation with core body temperature $(\mathrm{Ng} \&$ Kaw 2006). However, some limitations such as environmental factors could influence the IRT result (Church et al. 2014).

Body temperature of cattle can be used to evaluate health status, stress, measure thermal balance, and feed efficiency. Practice of temperature monitoring is useful for early detection of diseases in cattle. For instance, cows diagnosed with pneumonia had reticular temperatures 7.5 times higher than normal temperature (Adams et al. 2013). Injured skin has been shown to have a temperature 4.6 to $5.4^{\circ} \mathrm{C}$ higher than the surrounding normal skin (Poikalainen et al. 2012). Change in body temperature also can occur when an animal gets stressed. As the hypothalamic-pituitaryadrenocortical axis is activated, catecholamine and cortisol concentrations increased, and as a consequence heat is produced (Schaefer et al. 2004). Increased temperature in several regions of the body of cattle has a positive correlation with physiological parameters such as respiratory frequency, heart rate and panting score; all of these could be used as sign of stress (McManus et al. 2016). Body temperature can also be used to estimate production efficiency. Montanholi et al. (2010) reported that $70 \%$ ofvariation of efficiency feed was explained by body surface temperature. Cattle production in Indonesia is facing some constraints. Quality and quantity of feed in Indonesia are the most important major constraints. Therefore, many studies are focusing on evaluation of feed efficiency. The method that commonly used is using digestibility feed either in vitro or in vivo. Another constraint is animal diseases. Most of cattle diseases in Indonesia are caused by microorganism such as brucellosis, anthrax, jembarana, etc. These major constraints have relationship with changes in body temperature.

This article is aimed to describe the utilization of IRT in cattle production system and the potency of IRT application in Indonesia.

\section{THERMOREGULATION OF CATTLE}

Process of maintaining body temperature is known as thermoregulation. Two main processes involved in thermoregulation are: (1) Processing heat production from the main organs, and (2) Balancing heat production and dispersion processes and central heat removal (Sellier et al. 2014). These processes will be activated if body temperature moves above or below the thermal comfort zone due to both external or internal factors, and heat is absorbed or released from the body. The thermoregulation process in principle is the process of heat balance between heat production and the release of the heat.

Body temperature defines the ability of body to release and absorb heat. Usually, the body temperature of homoeothermic animal is relatively constant. However, in certain circumstances, the body temperature could be changed. Body temperature is usually used as a sign of animal health and wellbeing. For example, body temperature has been shown to increase in animals suffering with pneumonia (Adams et al. 2013), mastitis (Colak et al. 2008; Hovinen et al. 2008; Adams et al. 2013), bovine respiratory disease (Timsit et al. 2011), and stress (González-Alonso et al. 1999).

\section{Peripheral temperature}

Soerensen \& Pedersen (2015) categorized skin into two types of thermal: thermal window and nonthermal window. Thermal window skins or body surfaces are relatively poorly covered in coat or even entirely devoid of insulation and well perfused by blood and as such provides a "window" to body core temperature (Sellier et al. 2014; Soerensen \& Pedersen 2015). Body surfaces in the thermal window category include ear base, eye region, and udder. Skin areas where thermoregulation is controlled by limited blood perfusion to the outer skin are categorized as nonthermal windows, for example, ear flaps and shoulders.

Peripheral temperature or skin temperature is influenced by environmental conditions, core body temperature, and the peripheral blood system regulation. Non-thermal window skin is more strongly influenced by ambient temperature compared with thermal window areas (Soerensen \& Pedersen 2015). The strong association between body surface temperature and core body temperature was shown by fluctuations in the ewe's core body surface as an effect of parturition (Nabenishi \& Yamazaki 2017).

\section{Core temperature}

Core temperature refers to body temperature or inner body temperature (Parson 2003; Soerensen \& Pedersen 2015). The function of the principle organs such as heart, brain, liver, and kidney, under normal conditions generates about $60 \%$ of body heat (i.e. core body temperature) (Sellier et al. 2014). An endothermic animal has the ability to regulate their core body temperature so that it remains constant under normal 
condition. Metabolism processes and blood flow affect core temperature (McCafferty et al. 2015). There is a diurnal pattern of body temperature known as circadian rhythm. This rhythm causes core temperature to increase from mid-morning up to afternoon and decline from evening to the early morning (Wrenn et al. 1961).

Body temperature can be measured at various locations such as at the rectum, ear, reticulorumen, vagina, and udder. The most common method used to obtain the body temperature is rectal temperature, as it is simple and accurate. However, there were factors that could influence the measurement temperature at the rectum include the procedure of measurement $\left(0.5^{\circ} \mathrm{C}\right.$ variations), the type of thermometer $\left(0.3^{\circ} \mathrm{C}\right.$ variations), the depth of penetration into the rectum $\left(0.4^{\circ} \mathrm{C}\right.$ variations) (Burfeind et al. 2010). Measuring of body temperature at reticulorumen results in higher and more varied temperatures than rectal temperature. Core body temperature was measured with vaginal temperature associated with rectal measures (Vickers et al. 2010).

\section{THE ROLE OF INFRARED THERMOGRAPHY IN THERMOREGULATION}

\section{The accuracy of infrared thermography in detecing the peripheral temperature}

Measuring peripheral or skin temperature with IRT requires measurement of the absorption of the thermal energy emitted by the surface object. Infrared thermography showed slightly more responsive in measurement of skin temperature for clinical purposes in comparison with thermistor, and a traditional device and index of responsiveness of 4.2, compared to 3.6 and 3.6, respectively (Burnham et al. 2006). The correlation between IRT and thermistor for the measurement of skin temperature during resting and exercise in both cold and hot environments is very high (r: 0.98) (Buono et al. 2007). Buono et al. (2007) also found a high correlation (r: 0.99) between an infrared non-contact sensor and a thermocouple contact sensor for monitoring skin temperature, but also found that the result of infrared non-contact sensor can be in error due to the change of angle and the distance (Hershler et al. 1992). Furthermore, ambient temperature and humidity directly influence the IRT-detected temperature (Loughmiller et al. 2001).

Infrared thermography is able to distinguish the difference of temperature for each part of body. Salles et al. (2016) mapped the body surface temperature of cattle using the IRT and discovered that the right flank, left flank, and forehead all had high correlations with the temperature and humidity index $(0.85 ; 0.81$; and 0.81 respectively). That study found that the highest temperature was at the eye area $\left(36.88^{\circ} \mathrm{C}\right)$ and the lowest was at the forehead $\left(28.40^{\circ} \mathrm{C}\right)$. The least variation in temperature was found in the right eye area (sd: \pm 0.44$)$ and the largest variation at the cranial left foreleg (sd: \pm 2 ).

\section{The accuracy of infrared thermography in detecting the core temperature}

Measuring core body temperature means measuring the temperature inside the body accurately. Several part of body surface areas, relying on a thermal window which is body surfaces that are poorly insulated by hair and so provide a "window" to body core temperature (Soerensen \& Pedersen 2015) that can represent core body temperature. Measuring core body temperature trough those body parts can be obtained using IRT. Eye temperature measured with IRT has an association with rectal temperature, and has $74.6 \%$ sensitivity and $92.3 \%$ specificity in detection of febrile ponies (Johnson et al. 2011). Additionally, it was found that initial ocular surface temperature after blinking in humans is an indicator of core body temperature (Tan et al. 2016). The sensitivity and specificity of ear infrared temperature was 83 and $88 \%$, respectively to predict body temperature of $\geq 38^{\circ} \mathrm{C}$ (Chan et al. 2004). An ear and eye (lateral can thus and areas near the medial temperature measured by those infrared tools correlated well with core body temperature (Schmidt et al. 2013). Infrared thermography-detected temperatures at front, cheek, eye, ocular area, ribs, flank, rump, and feet of cattle are positively associated with rectal temperature (Martello et al. 2016).

In addition, it was found that the highest correlation was obtained in the front site dominated by the brain which regulates the body temperature via central nervous system (CNS) (Martello et al. 2016). However, Sapkota et al. (2016) discovered that core body temperature could be estimated by skin surface temperature by IRT was only in the thermoneutral condition. Their study resulted that when animal was recovered from acute heat stress to thermoneutral condition, the skin temperature drastically dropped within $10 \mathrm{~min}$ whereas core body temperature still elevated for $30 \mathrm{~min}$.

\section{The use of infrared thermography in detecting temperature fluctuation}

Infrared thermography is able to detect the small change of temperature. Infrared thermography was able to detect the elevated temperature at several sites on the body of calves that were inoculated with BVDV (Schaefer et al. 2004). The change of temperatures per day detected for nose, ear, side, and dorsal consist of $0.35 ; 0.4 ; 0.19$; and $0.18^{\circ} \mathrm{C}$ respectively. Increased 
temperature from the base line, due to foot-and-month disease virus (FMDV) was detected by IRT, preclinical and post-clinical phase for cattle that were either directly inoculated and had contact with the FMDV, or had received a FMDV vaccine. Infrared thermography was able to detect elevated temperatures from the baseline to pre-clinical stage of $0.5^{\circ} \mathrm{C}$ (Rainwater-Lovett et al. 2009). A study by Scolari (2010) showed IRT could detect fluctuation of temperature around the vulvar skin during oestrus. Infrared thermography also detected a fleeting depression in eye temperature of cow for several seconds during a fear or pain response related to the handling (Stewart et al. 2008). Likewise, the decrease of temperature $\left(\Delta \mathrm{T} \sim 1^{\circ} \mathrm{C}\right)$ in several areas (eye bulb, the periocular area, and the ear skin) of rabbit was detected by IRT during stress condition (Ludwig et al. 2010).

\section{APPLICATION OF INFRARED THERMOGRAPHY FOR ASSESSING LIVESTOCK HEALTH AND WELFARE}

Under normal conditions, the body temperature of mammals as homoeothermic animals is constant for several reasons. Temperature changes can affect protein conformation and enzyme activity. Thereby changing the temperature in the animal will affect cellular reaction rate. The change in body temperature affects the kinetic energy possessed by each molecule of a substance, so the increase in body temperature will give greater probability to the various particles of substance to collide with each other. This causes an increase in reaction rate in the body; if the reaction rate is not controlled then this will be detrimental.

Body temperature is a critical point in health and wellbeing of cattle. Hyperthermia, fever, or inflammation generates elevation of body temperature. A high body temperature due to hyperthermia is triggered when the body's ability to transfer heat effectively is impaired. Increasing body temperature due to fever is usually related to illness or diseases. Fever is defined as the increase in body temperature from the baseline temperature by more than one standard deviation (Bligh \& Johnson 1973). Production of heat due to inflammation is associated within fiction or damaged tissue (Štvrtinová et al. 1995).

\section{Application of infrared thermography for assessing inflammatory processes}

Inflammation is the immune system's response to a challenge (usually bacteria and viruses). Signs of inflammation include heat, redness, swelling, pain, and loss of function (NCBI 2015). Increased heat in an area with inflammation could be detected remotely by IRT, and possibly earlier, than with methods which rely on the animal to display visual or behavioral symptoms.

Infrared thermography has been used for early detection of hoof lesions in dairy cows by capturing the elevated temperature on the feet affected by lesion (Figure 1) (Alsaaod \& Büscher 2012). Skin and coronary band temperature was significantly higher for cows with digital dermatitis and feet skin temperature was elevated when infected with M-lesion (Alsaaod et al. 2014). The foot temperature of cows with digital dermatitis and other lesions was higher compared to unaffected cows for every type of foot presentation (unclean foot, cleaned foot, and lifted foot), therefore digital dermatitis and lesion in cow could be detected earlier with IRT (Stokes et al. 2012). Furthermore, determining the right threshold temperature for each feet's presentation (either clean or dirty feet) is important to increase the sensitivity and accuracy of IRT. Its lowering threshold temperature from 27 to $22^{\circ} \mathrm{C}$ for clean feet could be resulting in a false positive diagnosis for foot lesions. However, IRT could not detect different lesion pathologies as the study showed that the temperature between different lesion types did not differ (Stokes et al. 2012).

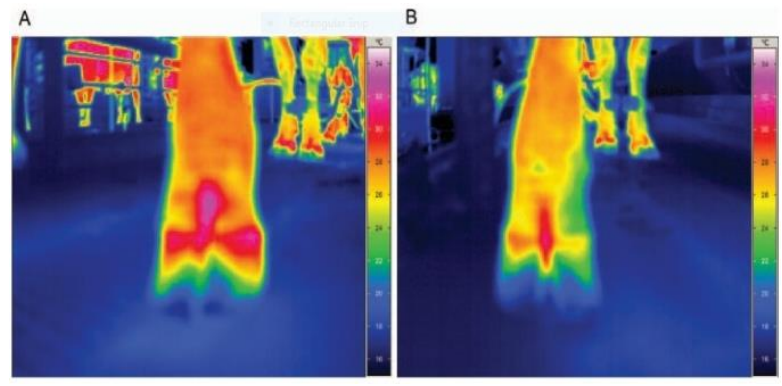

A: Left (1: Lesion); B: Right (0: Sound) hind hoof obtained before claw trimming. The highest temperature was represented by the red colour

Figure 1. Infrared images of plantar

Source: Alsaaod \& Büscher (2012)

Many studies have demonstrated that IRT is a suitable tool to detect mastitis in the dairy cow. A positive correlation between infrared thermography and California mastitis test (CMT) and somatic cell count (SCC) to screen subclinical mastitis, since CMT and SCC are reliable tests and reliable biomarker tools to detect subclinical mastitis (Polat et al. 2010; Samara et al. 2014). Infrared thermography was able to perceive even a small change in skin surface temperature of the mammary gland in responding to varying degrees of mammary gland infection severity as reflected by the CMT score (Colak et al. 2008). Infrared thermography could distinguish the elevated temperature on the udder when the mammary gland was injected by endotoxin infusion to induce inflammation (Scott et al. 2000). 
Infrared thermography was also able to detect the change of temperature of the udder four hours after injection of Escherichia coli lipopolysaccharide in the mammary gland, even though the first signs of clinical mastitis in the milk occurred two hours earlier than temperature change in the udder (Hovinen et al. 2008).

\section{Application of infrared thermography for assessing disease}

The ability of IRT as a feasible screening technology is able to quickly and accurately identify an animal with an infection has been shown by several studies. Infrared thermography has demonstrated the ability to identify the early stages of infection in calves which were injected with BVDV several days to one week before the clinical signs occurred (Schaefer et al. 2004). The temperature of the eye area (the most sensitive region) was significantly increased within 24 hours after inoculation with the virus. Infrared thermography was able to detect bovine respiratory disease BRD infection before clinical signs manifested. According to clinical scores, the core temperature of calves positive to $\mathrm{BRD}$ increased to $38.98^{\circ} \mathrm{C}, 4$ to 6 days before the onset of illness and at the day of illness was $40.17^{\circ} \mathrm{C}$. An elevated temperature in BRD-positive cattle 4 to 6 days' prior first BRD symptom appeared was detected early by IRT (Schaefer et al. 2007). Predictive of IRT for both positive and/or negative BRD infection based on change of body surface temperature, as well as test efficiency were more accurate than industry standard practice clinical scoring. (Schaefer et al. 2007).

\section{Application of infrared thermography for assessing cattle welfare}

One of the physiological indicators of poor welfare of animals is elevated or depressed body temperature; hence IRT can be utilized to identify a stressed animal. Eye temperature decreased after infusion with epinephrine (Stewart et al. 2010). Concentration of epinephrine in blood is associated with hyper-acute pain and the pain response of animals. This finding explained earlier research which found eye temperature rapidly decreased due to rough handling procedures (hitting, startling, electric prod and startling plus shouting) (Stewart et al. 2008). Both experiments used IRT to measure the eye temperature, indicating IRT is useful to assess the pain and disruption of cattle during handling.

When the stressors persist for a longer time on the animal, the hypothalamic-pituitary-adrenal (HPA) axis will be activated due to the increase of catecholamine and cortisol levels, impact on the change in heat production (Stewart et al. 2005). There were positive correlations between eye temperature detected by IRT and HPA activity (Cook et al. 2001), and eye temperature detected by IRT and saliva cortisol (Valera et al. 2012). When the acute stress response, or "fight or flight" reaction is triggered, sympathetically mediated vasocontraction occurs in order to minimize the blood loss is marked by rapid short term drop in skin temperature. Skin temperature drops in chickens exposure to acute handling stress is able to be detected by IRT (Herborn et al. 2015). Infrared thermography detected the decreased temperature in tail and paw of rats which experienced fear (Vianna \& Carrive 2005). These studies proved the ability of IRT to accurately detect stress responses which were marked by a drop in skin temperature.

\section{APPLICATION IRT FOR MEASURING FEED EFFICIENCY}

Some studies on energy metabolism have shown that beef cattle with either lower heat loss and methane production is more efficient in beef production (Castro Bulle et al. 2007; Hegarty et al. 2007). Therefore, more efficient animals have lower body surface temperature compared with less efficient animals. The heat produced by the animals is greatly dissipated through the skin which can be captured using IRT. Therefore, body surface temperature could be used to detect the efficiency of beef cattle.

Infrared thermography has been used as a noninvasive tool for predicting methane production and emission, being simpler than conventional method (Montanholi et al. 2008). Methane production could be assessed using IRT through analysis of the temperature difference between left and right flanks in the postprandial period which is up to $100 \mathrm{~min}$ after a meal (Montanholi et al. 2008). The temperature difference between right and left flanks followed the methane emission pattern (Montanholi et al. 2008).

Infrared thermography could be used to assess gain efficiency of individual animals in pen without disturbing them. A significant correlation between surface temperature and dry matter intake (DMI), average daily gain $(A V G)$ and feed to gain ratio $(F: G)$ was detected in bull (Huntington et al. 2012). Assessment of feed efficiency using IRT was cheaper and lower prediction limit when compared to conventional feed intake measurement (Montanholi et al. 2010). The body surface temperature (IRT) accounted for more than $70 \%$ of the residual feed intake variation found in the three groups of traits evaluated together. This result indicated an important application of IRT (Montanholi et al. 2010).

The distal portion of the hindquarters and face temperatures were the most appropriate body sites to 
indirectly assess feed efficiency in cattle using IRT. Feet and cheek temperature appear to be the most promising body locations for indirectly assessing feed efficiency in cattle (Montanholi et al. 2009).The feet were the most appropriate location for predicting heat production using IRT (Montanholi et al. 2008).

Considering the impact of feeding and milking on IRT measurements, care must be taken to allow for wider utilization of this technology of this technology for predicting heat and methane production. Therefore, the best time for measuring surface temperature measured was up to 100 minutes after a meal or called postprandial period. After milking the cows, the skin surface temperature of different body locations consistently decrease between 0.4 and $0.8^{\circ} \mathrm{C}$ while the heat production increased (Montanholi et al. 2008).

\section{POTENCY OF APPLICATION IRT IN CATTLE PRODUCTION IN INDONESIA}

There was hardly any information or study on the application of IRT on cattle production in Indonesia. While, low feed efficiency, diseases, and welfare issues are the most constraints in cattle production in Indonesia. All these issues have a relationship with changes of body temperature; therefore, IRT can be used as a simple tool for early detection for those issues.

Native grass and residues crops are commonly used as main feed of cattle which are known as low quality feed. The low quality feed has low digestibility resulting in high methane production during the fermentation in the rumen. Methane energy loss per gross energy intake in beef cattle ranges from 8.4 to $10 \%$ (Tangitwattanachai et al. 2015). Methane production is significantly affecting heat production (Kumar et al. 2016). Common methodologies for measuring feed efficiency used in Indonesia are bio assays. The limitations of this method are longer times to do the assays and many tools are required. By using IRT to detect the change of body temperature due to heat metabolic can be useful to figure out quickly feed efficiency in the field.

Infrared thermography can be a very useful tool as early detector for several cattle diseases. The main diseases which often appear and cause a great economic loss in cattle production in Indonesia are brucela, anthrax, mastitis, helminthiasis, and jembrana (Putro 2004; Zulfikar 2014). The main early sign of these diseases are increasing body temperature called fever (Zulfikar 2014). Early detection in body temperature change before the symptom occurs could be helpful for further effort in controlling the disease.

\section{CONCLUSION}

There are several parts of the cattle body can be used as a thermal window which can describe the core body temperature. Therefore, the change of body surface temperature of cattle at several specific parts of body areas can describe their physiological condition. The ability of IRT to detect even little change of body surface temperature has been used as a useful tool to detect cattle condition. IRT has been utilized widely in cattle production such as early detector some cattle illness, cattle welfare, and even feed efficiency. However, some limitations such as impact of feeding time, milking, and dirty fur should be considered during measuring body temperature using IRT.Utilization of IRT in Indonesia will have a great potency because some important constraints in cattle production in Indonesia such as diseases and low feed efficiency may have strong correlation with body temperature change.

\section{ACKNOWLEDGMENTS}

I would like to thank for Dr. Frances Cowlay of University of New England and Dr. Muchamad Yusron of Indonesian Center for Agricultural Technology Assessment and Development for mentoring this article.

\section{REFERENCES}

Adams AE, Olea-Popelka FJ, Roman-Muniz IN. 2013. Using temperature-sensing reticular boluses to aid in the detection of production diseases in dairy cows. J Dairy Sci. 96:1549-1555.

Alsaaod M, Büscher W. 2012. Detection of hoof lesions using digital infrared thermography in dairy cows. J Dairy Sci. 95:735-742.

Alsaaod M, Syring C, Dietrich J, Doherr MG, Gujan T, Steiner A. 2014. A field trial of infrared thermography as a non-invasive diagnostic tool for early detection of digital dermatitis in dairy cows. Vet J. 199:281-285.

Bligh J, Johnson KG. 1973. Glossary of terms for thermal physiology. J Appl Physiol. 35:941-961.

Buono MJ, Jechort A, Marques R, Smith C, Welch J. 2007. Comparison of infrared versus contact thermometry for measuring skin temperature during exercise in the heat. Physiol Meas. 28:855.

Burfeind O, von Keyserlingk MAG, Weary DM, Veira DM, Heuwieser W. 2010. Short communication: repeatability of measures of rectal temperature in dairy cows. J Dairy Sci. 93:624-627.

Burnham RS, McKinley RS, Vincent DD. 2006. Three types of skin-surface thermometers: A comparison of reliability, validity, and responsiveness. Am J Phys Med Rehabil. 85:553-558. 
Castro Bulle FCP, Paulino P V., Sanches AC, Sainz RD. 2007. Growth, carcass quality, and protein and energy metabolism in beef cattle with different growth potentials and residual feed intakes. J Anim Sci. 85:928-936.

Chan L-S, Cheung GTY, Lauder IJ, Kumana CR. 2006. Screening for fever by remote-sensing infrared thermographic camera. J Travel Med. 11:273-279.

Church JS, Hegadoren PR, Paetkau MJ, Miller CC, RegevShoshani G, Schaefer AL, Schwartzkopf-Genswein KS. 2014. Influence of environmental factors on infrared eye temperature measurements in cattle. Res Vet Sci. 96:220-226.

Colak A, Polat B, Okumus Z, Kaya M, Yanmaz LE, Hayirli A. 2008. Short communication: Early detection of mastitis using infrared thermography in dairy cows. J Dairy Sci. 91:4244-4248.

Cook NJ, Schaefer AL, Warren L, Burwash L, Anderson M, Baron V. 2001. Adrenocortical and metabolic responses to ACTH injection in horses: An assessment by salivary cortisol and infrared thermography of the eye. Can J Anim Sci. 81:621.

González-Alonso J, Teller C, Andersen SL, Jensen FB, Hyldig T, Nielsen B. 1999. Influence of body temperature on the development of fatigue during prolonged exercise in the heat. J Appl Physiol. $86: 1032-1039$

Hegarty RS, Goopy JP, Herd RM, McCorkell B. 2007. Cattle selected for lower residual feed intake have reduced daily methane production. J Anim Sci. 85:1479-1486.

Herborn KA, Graves JL, Jerem P, Evans NP, Nager R, McCafferty DJ, McKeegan DEF. 2015. Skin temperature reveals the intensity of acute stress. Physiol Behav. 152:225-230.

Hershler C, Conine TA, Nunn A, Hannay M. 1992. Assessment of an infra-red non-contact sensor for routine skin temperature monitoring: A preliminary study. J Med Eng Technol. 16:117-122.

Hovinen M, Siivonen J, Taponen S, Hänninen L, Pastell M, Aisla AM, Pyörälä S. 2008. Detection of clinical mastitis with the help of a thermal camera. J Dairy Sci. 91:4592-4598.

Huntington G, Cassady J, Gray K, Poore M, Whisnant S, Hansen G. 2012. Use of digital infrared thermal imaging to assess feed efficiency in Angus bulls. Prof Anim Sci. 28:166-172.

Johnson SR, Rao S, Hussey SB, Morley PS, Traub-Dargatz JL. 2011. Thermographic eye temperature as an index to body temperature in ponies. J Equine Vet Sci. 31:63-66.

Kumar S, Singh SV, Pandey P, Kumar N, Hooda OK. 2016. Estimation of metabolic heat production and methane emission in Sahiwal and Karan Fries heifers under different feeding regimes. Vet World. 9:496-500,

Loughmiller JA, Spire ME, Dritz SS, Fenwick BW, Hosni MH, Hogge SB. 2001. Relationship between mean body surface temperature measured by use of infrared thermography and ambient temperature in clinically normal pigs and pigs inoculated with Actinobacillus pleuropneumoniae. Am J Vet Res. 62:676-681.

Ludwig N, Gargano M, Luzi F, Carenzi C, Verga M. 2007. Technical note: Applicability of infrared thermography as a non-invasive measurement of stress in rabbit. World Rabbit Sci. 15:199-206.

Martello LS, e Silva SDL, da Costa Gomes R. da Silva Corte RRP, Leme PR. 2016. Infrared thermography as a tool to evaluate body surface temperature and its relationship with feed efficiency in Bos indicus cattle in tropical conditions. Int J Biometeorol. 60:173-181.

McCafferty DJ, Gallon S, Nord A. 2015. Challenges of measuring body temperatures of free-ranging birds and mammals. Anim Biotelemetry. 3:33.

McManus C, Tanure CB, Peripolli V, Seixas L, Fischer V, Gabbi AM, Menegassi SRO, Stumpf MT, Kolling GJ, Dias E, Costa JBG. 2016. Infrared thermography in animal production: An overview. Comput Electron Agric. 123:10-16.

Montanholi YR, Odongo NE, Swanson KC, Schenkel FS, McBride BW, Miller SP. 2008. Application of infrared thermography as an indicator of heat and methane production and its use in the study of skin temperature in response to physiological events in dairy cattle (Bos taurus). J Therm Biol. 33:468-475.

Montanholi YR, Swanson KC, Schenkel FS, McBride BW, Caldwell TR, Miller SP. 2009. On the determination of residual feed intake and associations of infrared thermography with efficiency and ultrasound traits in beef bulls. Livest Sci. 125:22-30.

Montanholi YR, Swanson KC, Palme R, Schenkel FS, McBride BW, Lu D, Miller SP. 2010. Assessing feed efficiency in beef steers through feeding behavior, infrared thermography and glucocorticoids. Animal. 4:692-701.

Nabenishi H, Yamazaki A. 2017. Decrease in body surface temperature before parturition in ewes. J Reprod Dev. 63:185-190.

NCBI. 2015. What is an inflammation. National Center for Biotechnology Information [Internet]. Available from: https://www.ncbi.nlm.nih.gov/pubmedhealth/ PMH0072482/

$\mathrm{Ng}$ EYK, Kaw GJL. 2006. Infrared images and fever monitoring devices: physics, physiology, and clinical accuracy. In: Medical devices and system: Biomeical enginering handbook. Boca Raton (US): CRC Press.

Parsons K. 2014. Human thermal environments: The effects of hot, moderate, and cold environments on human health, comfort, and performance. Boca Raton (US): CRC Press.

Poikalainen V, Praks J, Veermäe I, Kokin E. 2012. Infrared temperature patterns of cow's body as an indicator for health control at precision cattle farming. Agron Res Biosyst Eng Spec. 10:187-194. 
Polat B, Colak A, Cengiz M, Yanmaz LE, Oral H, Bastan A, Kaya S, Hayirli A. 2010. Sensitivity and specificity of infrared thermography in detection of subclinical mastitis in dairy cows. J Dairy Sci. 93:3525-3532.

Putro PP. 2004. Pencegahan, pengendalian dan pemberantasan penyakit hewan menular strategis dalam pengembangan usaha sapi potong. Dalam: Setiadi B, Priyanti A, Handiwirawan E, Diwyanto K, Wijono DB, penyunting Strategi Pengembangan Sapi Potong dengan Pendekatan Agribisnis dan Berkelanjutan. Prosiding Lokakarya Nasional Sapi Potong. Yogyakarta, 8-9 Oktober 2004. Bogor (Indonesia): Puslitbangnak. hlm. 22-26.

Rainwater-Lovett K, Pacheco JM, Packer C, Rodriguez LL. 2009. Detection of foot-and-mouth disease virus infected cattle using infrared thermography. Vet $\mathrm{J}$. 180:317-324

Salles MSV, da Silva SC, Salles FA, Roma LC, El Faro L, Bustos Mac Lean PA, Lins de Oliveira CE, Martello LS. 2016. Mapping the body surface temperature of cattle by infrared thermography. J Therm Biol. 62:6369.

Samara EM, Ayadi M, Aljumaah RS. 2014. Feasibility of utilising an infrared-thermographic technique for early detection of subclinical mastitis in dairy camels (Camelus dromedarius). J Dairy Res. 81:38-45.

Sapkota A, Herr A, Johnson JS, Lay DC. 2016. Core body temperature does not cool down with skin surface temperature during recovery at room temperature after acute heat stress exposure. Livest Sci. 191:143147.

Schaefer AL, Cook N, Tessaro S V., Deregt D, Desroches G, Dubeski PL, Tong AKW, Godson DL. 2004. Early detection and prediction of infection using infrared thermography. Can J Anim Sci. 84:73-80.

Schaefer AL, Cook NJ, Church JS, Basarab J, Perry B, Miller C, Tong AKW. 2007. The use of infrared thermography as an early indicator of bovine respiratory disease complex in calves. Res Vet Sci. 83:376-384.

Schmidt M, Lahrmann K-H, Ammon C, Berg W, Schön P-C, Hoffmann G, Schmidt M, Lahrmann K-H, Ammon C, Berg W, et al. 2013. Assessment of body temperature in sows by two infrared thermography methods at various body surface locations. J Swine Heal Prod. 21:203-209.

Scolari SC. 2010. Investigation of skin temperature differentials in relation to estrus and ovulation in sows using a thermal infrared scanning. [Dissertation]. [Champaign (US)]: University of Illinois at Urbana.

Scott SL, Schaefer AL, Tong AKW, Lacasse P. 2000. Use of infrared thermography for early detection of mastitis in dairy cows. Canada J Anim Sci. 80:764.

Sellier N, Guettier E, Staub C. 2014. A Review of methods to measure animal body temperature in precision farming. Am J Agric Sci Technol. 2:74-99.
Soerensen DD, Pedersen LJ. 2015. Infrared skin temperature measurements for monitoring health in pigs: A review. Acta Vet Scand. 57:5.

Stewart M, Webster JR, Stafford KJ, Schaefer AL, Verkerk GA. 2010. Technical note: Effects of an epinephrine infusion on eye temperature and heart rate variability in bull calves. J Dairy Sci. 93:5252-5257.

Stewart M, Schaefer AL, Haley DB, Colyn J, Cook NJ, Stafford KJ, Webster JR. 2008. Infrared thermography as a non-invasive method for detecting fear-related responses of cattle to handling procedures. Anim Welf. 17:387-393.

Stewart M, Webster JR, Schaefer AL, Cook NJ, Scott SL. 2005. Infrared thermography as a non-invasive tool to study animal welfare. Anim Welf. 14:319-325.

Stokes JE, Leach KA, Main DCJ, Whay HR. 2012. An investigation into the use of infrared thermography (IRT) as a rapid diagnostic tool for foot lesions in dairy cattle. Vet J. 193:674-678.

Štvrtinová V, Jakubovský J, Hulin I. 1995. Inflammation and fever. Bratislava (Slovakia): Academic Electronic Press.

Tan LL, Sanjay S, Morgan PB. 2016. Repeatability of infrared ocular thermography in assessing healthy and dry eyes. Contact Lens Anterior Eye. 39:284-292.

Tangjitwattanachai N, Phaowphaisal I, Otsuka M, Sommart K. 2015. Enteric methane emission, energetic efficiency and energy requirements for the maintenance of beef cattle in the tropics. Japan Agric Res Q. 49:399-407.

Timsit E, Assié S, Quiniou R, Seegers H, Bareille N. 2011. Early detection of bovine respiratory disease in young bulls using reticulo-rumen temperature boluses. Vet J. 190:136-142.

Usamentiaga R, Venegas P, Guerediaga J, Vega L, Molleda J, Bulnes FG. 2014. Infrared thermography for temperature measurement and non-destructive testing. Sensors (Switzerland). 14:12305-12348.

Valera M, Bartolomé E, Sánchez MJ, Molina A, Cook N, Schaefer A. 2012. Changes in eye temperature and stress assessment in horses during show jumping competitions. J Equine Vet Sci. 32:827-830.

Vianna DML, Carrive P. 2005. Changes in cutaneous and body temperature during and after conditioned fear to context in the rat. Eur J Neurosci. 21:2505-2512.

Vickers LA, Burfeind O, von Keyserlingk MAG, Veira DM, Weary DM, Heuwieser W. 2010. Technical note: Comparison of rectal and vaginal temperatures in lactating dairy cows. J Dairy Sci. 93:5246-5251.

Wrenn T, Bitman J, Sykes J. 1961. Diurnal patterns of bovine body temperature. J Dairy Sci. 44:2077-2080.

Zulfikar. 2014. Gambaran penyakit infeksius pada ternak sapi dan cara pencegahan. J Lentera. 12:1-8. 